\title{
REFUSAL STRATEGIES EMPLOYED BY BULGARIAN AND ENGLISH NATIVE SPEAKERS WITH HIGHER STATUS INTERLOCUTORS
}

Polina Mitkova ${ }^{1}$

\begin{abstract}
This paper compares the refusal strategies employed by English and Bulgarian native speakers in business settings with interlocutors of a higher status. The data collecting tool is a discourse - completion task (DCT). The refusals are compared in terms of frequency of the semantic formulas and adjuncts. The findings indicate that refusals towards representatives of a higher status are most frequently realized through the semantic formula Reason/Explanation, followed by Regret/ Apology and Negation of the proposition for English native speakers or Statement of fact for Bulgarians. Some of the short patterns of strategies observed for Bulgarians are the combinations: Negation of the proposition and Statement of fact, Statement of fact and Warning, Statement of fact and Statement of limit and Statement of fact and Redirecting. These findings should benefit researchers, business people and negotiators who are to overcome intercultural, communicational and linguistic challenges in a globalized world.
\end{abstract}

Key words: business communication, negotiations, refusals, discourse - completion task, Bulgarian and English native respondents

\section{Introduction}

This study is part of a more comprehensive project on refusals in business communication. It presents data of Bulgarians' refusals in Bulgarian and English native speakers' refusals in English. Its main purpose is to discover the most frequently used refusal strategies by both groups in the communication with individuals of a higher status. The novelty of the research lies in the fact that it focuses on a little researched Slavic group as well as in the business setting of the scenarios administered to the respondents.

The importance of fields in linguistics such as interlanguage pragmatics is felt stronger nowadays among people engaged in international business communication. This has triggered interest in comparative studies in pragmatics dealing mostly with face-threatening speech acts, the refusal being one of them.

1. Ph.D Student, Department of English Studies, Shumen University, e-mail: polinamitkova@yahoo.com, ORCID: 0000-0003-0802-1546 
Not giving the answers expected or preferred by the hearer may have greater implications in business settings than it does in casual conversations.

Authors who have published extensively on the subject and proposed a taxonomy of their own are Takahashi, Beebe and Uliss-Weltz (1990), followed by another team of researchers Salazar, Safont and Codina (2009). Some Chinese authors work on refusals - Liao and Bresnahan (1996) compare American and Chinese refusal realizations with peers and higher status individuals; Jiayu (2004) compares Chinese and English speech acts of refusals in shopping activities and Honglin (2007) focuses on the directness aspect in refusals. Kádár (2012) investigated the epistolary corpus of the Chinese Ming and Qing dynasties. A brilliant epistolary sample is the marriage refusal written by an aristocrat lady to the widowed Chinese emperor. Ren (2016) focuses on date refusals in Chinese TV reality shows. Hong and Chen (2011) work on refusal realization in the context of press conference releases.

Al-Issa (2003), Al-Kahtani (2005), Al-Eryani (2007), Aliakbari and Changizi (2012) studied refusal realizations in Arabic languages. Lauper (1997) and Siebold and Busch (2015) elaborated on refusal realizations in the European language group. Lauper (1997) compares refusal realizations of English and Spanish speakers, while Siebold and Busch (2015) - of Spanish and German speakers.

Up to the present there are few studies dedicated to the performance of refusals in Slavic languages and in business communication. Nixdorf (2002) compares Russian with English and German speakers in their production of refusal speech acts. Comparative studies in the field of pragmatics are typically triggered by the geopolitical realities of a certain period, which at the time were marked by the return of many German expatriates to their homeland from Russia.

The questions we intend to answer in this paper are what the differences, similarities or the overlapping features in refusal performance are when they are carried out by Bulgarian and English native speakers with individuals of higher status i.e. in a business interaction between an employee and an employer (see scenario \#2 from Appendix A - when a boss asks an employee to stay late at work the day before their birthday, or scenario $\# 5$ - an employee to give a boss a lift back home).

\section{Materials and Methods}

The aim of this comparative study is to look into the refusal strategies employed by English and Bulgarian native speakers in business settings and to report on the most frequently used strategies by both groups with respect to status. Both groups' participants were given a tailor-made discourse-completion task (DCT) in their native language in the form of a quiz titled "Psycholinguistic 
experiment". It consists of 12 work-related situations identical for both groups (see Appendix A). Its subtitle "How do you refuse?" steers the participants into ways of realizing refusals. The participants were additionally instructed to use refusals in each of the scenarios in writing as if there were no possibilities for them to accept the suggested ideas.

The quiz was designed to incorporate scenarios with an eliciting act (mostly requests, suggestions, invitations etc.) coming from individuals of the same, higher and lower status. The status of the requestee was identified with an equal sign $(\Leftrightarrow)$ for a request coming from an equal status individual; a downwards arrow $(\downarrow)$ for a request coming from a higher status individual and an upwards arrow ( $\uparrow$ ) for a request coming from a lower status individual. The additional feature of status identification was added because some of the scenarios (\#8 the client who spills coffee on the floor and asks you to clean up the mess she created) raised the question of how to interpret the status of the client. Depending on what the business tenets in the respective culture are, the client may always come first and be entitled to the best service (that would qualify this elicitation act as one coming from a person of a higher status). The clients can, however, be on an equal footing with the staff or maybe of a lower status, as it was initially implied. Since we are interested in the refusal strategies and not so much in their cultural implications, we left these considerations for future research. Another scenario that received a lot of oral or written comments was scenario \#6 concerning donations that are being collected for a badly injured colleague from work. Many of the participants were reluctant to refuse stating that such behavior would be inhumane and they would never act in such a manner were it to happen in real life. The written samples from participants who misunderstood the quiz and answered only with "Yes/ No" (meaning probably that they would refuse or not in the given situations, but not writing how exactly) were excluded from the data that was subsequently analyzed.

The empirical data were obtained mostly via an online DCT quiz. A total of 105 English native speakers (ENS) responded to the English version of the quiz - 75 students from Iowa State University, aged between 18 and 25, majoring in economics. The rest of the informants are aged 23 to 71 with the British being the most numerous group of 20 people, followed by 14 Americans, 4 Australians, 2 Irish, 1 Scottish and 1 British/Australian. They submitted a paper version of the quiz (see the link in the references) directly to the researcher at the BETA - IATEFL Annual International Conference 2017 and at other random locations in Varna, Bulgaria.

The Bulgarian native informants (BNS), who filled in the Bulgarian version of the quiz are 110 - 30 students from the Varna University of Management, aged between 18 and 23, majoring in economics, software sciences or culinary 
arts. The majority of the rest of the informants are middle-aged individuals with various professions with the oldest informant being 67 years-old, as can be learned from the demographic information of the quiz.

\section{Data Analysis}

A modified version of Salazar, Safont and Codina's classification (2009) was used. It includes some entries from Beebe, Takahashi and Uliss-Weltz's (1990) taxonomy. Both classifications are "developed for single turn responses" (Gass $\&$ Houck, 1999). Instead of looking at the refusal as consisting of a head act and supportive moves (the Blum-Kulka et al.'s approach, 1989), Gass and Houck's approach was followed. They "applied the classification to all the acts that could be ... directly involved in negotiating the refusal" which "sometimes resulted in several acts in the same turn being treated as refusal strategies" (Gass \& Houck, 1999).

When analyzing the samples, we paid attention to the different kinds of semantic formulas and adjuncts and calculated their frequency for each scenario for both subject groups in order to discover the most prevalent ones. When coding the refusals, we tried to stay within the designated category. If a respondent in scenario \#7 refuses saying "It's not my job", this was coded as Statement of fact due to brevity of expression instead of as Reason/ Explanation which tended to be more long-winded. When a refusal consists of several ideas e.g. "How much are most people giving? I'm out of money at the moment." each idea is coded as a separate strategy, here Question and Reason/Explanation, because explanations tend to be personal. It has to be noted that there will always be differences in interpretation of the semantic formulas by different coders. The coding for this research was conducted by a single coder, which guarantees a certain level of consistency. If the study is to be replicated in the future by different researchers, their interpretation of the results may vary from what is being presented here.

\section{Research Findings}

Table 1 summarizes the information about the most frequent refusal strategies used by BNSs and ENSs. In scenarios \#2, \#5 and \#7 the requests comes from the boss. ${ }^{2}$

2. See the whole quiz in Appendix A. at the end. 
Table 1. Frequency of Semantic Formulas in Refusal of Request from a Person of a Higher status

\begin{tabular}{|l|l|l|l|}
\hline $\begin{array}{l}\text { Scena- } \\
\text { rios }\end{array}$ & $\begin{array}{l}\text { \#2 working late } \\
\text { before birthday }\end{array}$ & \#5 a lift back home & $\begin{array}{l}\text { \#7 taking up the tasks } \\
\text { of someone }\end{array}$ \\
\hline $\begin{array}{l}1^{\text {st }} \text { most } \\
\text { used }\end{array}$ & $\begin{array}{l}\text { Reason/Explana- } \\
\text { tion } \\
\text { ENS } 57 \% \\
\text { BNS 62 \% }\end{array}$ & $\begin{array}{l}\text { Reason/Explanation } \\
\text { ENS 61\% } \\
\text { BNS 50\% }\end{array}$ & $\begin{array}{l}\text { ENS Reason/ } \\
\text { Explanation 45\% } \\
\text { BNS Statement } \\
\text { of Fact 31\% }\end{array}$ \\
\hline $\begin{array}{l}2^{\text {nd }} \text { most } \\
\text { used }\end{array}$ & $\begin{array}{l}\text { Regret/Apology } \\
\text { ENS 27\% }\end{array}$ & $\begin{array}{l}\text { Regret/ Apology } \\
\text { ENS 35\% } \\
\text { BNS 41 \% }\end{array}$ & $\begin{array}{l}\text { Negation of Proposi- } \\
\text { tion } \\
\text { ENS 13\% } \\
\text { BNS 25\% }\end{array}$ \\
\hline $\begin{array}{l}3^{\text {rd }} \text { most } \\
\text { used }\end{array}$ & $\begin{array}{l}\text { Negation of } \\
\text { Proposition } \\
\text { ENS 19\% } \\
\text { BNS 25\% }\end{array}$ & $\begin{array}{l}\text { ENS Negation } \\
\text { of Proposition 17\% } \\
\text { BNS Statement of Fact } \\
31 \%\end{array}$ & $\begin{array}{l}\text { Regret/ Apology } \\
\text { ENS 12\% } \\
\text { Redirecting ENS } 12 \%\end{array}$ \\
\hline $\begin{array}{l}4^{\text {th }} \text { most } \\
\text { used }\end{array}$ & $\begin{array}{l}\text { ENS Questions - } \\
12 \% \\
\text { BNS Statement of } \\
\text { fact 20\% }\end{array}$ & $\begin{array}{l}\text { ENS Redirecting 9, 6\% } \\
\text { BNS Negation of Prop- } \\
\text { osition/ Faulty Features } \\
18 \%\end{array}$ & $\begin{array}{l}\text { ENS Plain Indirect } 11 \% \\
\text { BNS Reason / } \\
\text { Explanation 16\% }\end{array}$ \\
\hline $\begin{array}{l}5^{\text {th }} \text { most } \\
\text { used }\end{array}$ & $\begin{array}{l}\text { ENS Plain Indirect } \\
-7,7 \% \\
\text { BNS Willingness/ } \\
\text { Postponement }-12 \%\end{array}$ & $\begin{array}{l}\text { ENS Statement of } \\
\text { Fact, Condition 5,8 } \% \\
\text { BNS Softeners 8,2\% }\end{array}$ & $\begin{array}{l}\text { ENS Statement of } \\
\text { Fact, Condition 7, 7\% } \\
\text { BNS Warning/Willing- } \\
\text { ness 13\% }\end{array}$ \\
\hline
\end{tabular}

When an action is requested by a speaker of a higher status, English native speakers (ENSs) tend to resort to the semantic formula Reason/Explanation as their first choice, followed by Regret/Apology or Negation of the proposition. "Due to the authority aspect in business settings interlocutors opt for safer strategies using Reason/ Explanation and less often and when the degree of imposition changes (as is the case in scenario \#7 from the quiz - see Appendix A) either the more direct Statement of fact or Condition or evasive language as with Plain indirect strategy. When the case allows for involvement of the respondents in resolving the request they tend to use the Redirecting or Question strategy" (Mitkova, 2018).

When we compare with the Bulgarian corpus (the BNS figures) we can observe an overlap in scenario \#2 about a boss asking an employee to work late before the employee's birthday. The first three most used strategies are identical with those used by ENSs. As for the strategies occupying 4th and 5th positions Bulgarian native speakers (BNSs) show preference for the more direct Statement of fact, while ENSs opt for the noncommittal Question strategy and the Plain indirect strategy. Like Spanish speakers (Siebold \& Busch, 2015) BNSs prefer to express Willingness and would rather postpone the activity for a later and 
more convenient stage than abandon it completely. In scenarios \#5 and \#7 we have respectively 2 strategies that are in the identical positions as those in the ENS data (\#5 - Reason/ Explanation and Regret/ Apology; \#7 - Negation of proposition and Regret/apology) and 1 strategy (\#5 - Negation of proposition; \#7

- Reason/ Explanation) in a swapped position, which shows that when dealing with higher status individuals both BNSs and ENSs tend to choose very similar strategies.

\section{Discussion of the Differences and Similarities}

One can see in Table 1 above that the frequency of the strategy Statement of fact is lower with ENSs than it is with BNSs. The corpus reveals that ENSs refuse by it either standing alone (\#7 respondent 77 below) or in combination with maximum one more strategy - usually the direct Flat No strategy (\#7 respondent 101) or Regret/ Apology (\#7 respondent 52). This is to show that they tend to keep the utterance concise.

(77) "I will be distracted from my own work." (Statement of fact)

(101) "No. It's not my job." (Bluntness + Statement of fact)

(52) "I'm sorry but that's not a part of my job." (Regret/ Apology + Statement of fact)

The BNSs use it also as a stand-alone, but more often in a two-, three- and multiple-strategy combination, which adds a long-winded tone to the refusals. The shorter pattern Statement of fact + Negation of proposition (\#7 respondent 86 and Table 2) used by BNSs resembles the ENSs' Bluntness + Statement of fact pattern in terms of abruptness of expression. The development of shorter patterns into longer strategy combinations is visualized in Table 2 below. The most stable strategy combinations are circled in colors for ease of recognition.

(86) “Тези неща не са в моята сфера, не мога." - These things are not in my competency, I can't. (Statement of fact + Negation of proposition)

The other short patterns Statement of fact + Warning (\#7 respondent 41 and Table 2) and Statement of Fact + Redirecting (\#7 respondent 53), unique for BNS, give away their tendency to get involved in the problem at hand. What Gass and Houck (1999) notice in their research comparing native speakers' and non-native speakers' refusal realization is that "non-native speakers occasionally involved themselves in the native speaker's problems" and they observed "different degrees of supportive involvement" depending on the concern nonnative speakers have for the relationship. 
(41) “Поради факта, че самият аз съм натоварен - ще съм в състояние да изпълнявам задачите с голямо закъснение" - Due to the fact that I myself am very busy, I will be able to deliver the tasks with a big delay. (Statement of fact + Warning)

(53) “Моля, да ги разпределите към други колеги; посочвам заетостта си в момента (графика ми обикновено е пълен догоре)" - Could you please delegate them to other colleagues; I am enclosing my schedule, which is completely full. (Statement of fact + Redirecting)

Another short pattern used only by Bulgarians is the outright denial achieved through the combination of Statement of fact and Sarcasm (\#7 respondent 23). This set of strategies contrasts sharply with the generally more solution-oriented and face-saving tone of refusals in the BNS corpus.

(23) “Често оставам след работа, за да си изпълня преките задължения, ако взема и тези задачи, трябва да не се прибирам.” - I often stay after work to complete my tasks. If I take these tasks on top of mine, I won't make it home at all (Statement of fact + Sarcasm)

Table 2. Short patterns developed into longer strategy combinations used by BNSs

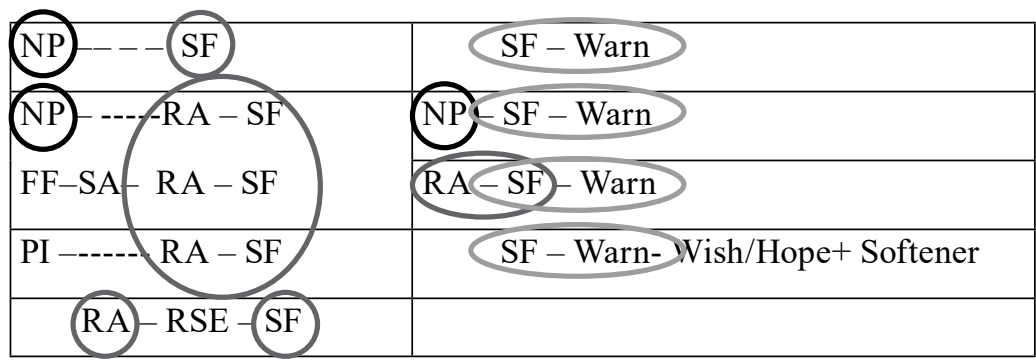

The short patterns common for both groups are the face-saving combinations of Regret/ Apology and Statement of fact (\#7 respondent 52 above and \#2 respondent 81 below) or Statement of fact and Postponement (\#2 respondent 54; \#7 respondent 94)

(81) “Съжалявам, имам семейни ангажименти.” - I'm sorry, I have family appointments. (Regret/ Apology + Statement of fact)

(54) “Шефе, имам личен ангажимент, ако не е критично спешно остава за утре." - Boss, I have personal engagement, if it isn't extremely urgent, I will do it tomorrow. (Statement of fact + Postponement)

(94) I haven't completed my current tasks. Once I have done them I will do the others. (Statement of fact + Postponement) 
In contrast to ENSs, Bulgarians tend to extend the short pattern Regret/ Apology - Statement of fact (see Table 2) and add to it Negation of proposition (\#7 respondent 33) and more rarely Faulty features paired with a Softener/ Address (\#7 respondent 64) or Plain indirect strategy (\#7 respondent 75).

(33) "Аз моите задачи не мога да свърша на време. Съжалявам, но няма да мога" - I cannot execute my own tasks on time. I am sorry, but I cannot manage. (Statement of fact + Regret/ Apology +Negation of proposition)

(64) “Съжалявам шефе, моите задължения напълно ми запълват работното време. Нямам свободен капацитет." - I am sorry, boss, my own duties take up completely my work schedule. I have no free capacity. (Regret/ Apology + Softener/ Address + Statement of fact + Faulty features)

(75) “Съжалявам, но нямам възможност. Имам твърде много задачи.” - I am sorry, but I won't be able to do it. I have too many tasks. (Regret/ Apology + Plain indirect + Statement of fact)

The use of these additional strategies, although intended to strengthen the validity of the fact mentioned, add a defensive note to the utterance and may be perceived by the interlocutor as a signal that negotiation is possible.

Following these lines, Bulgarians are inclined to incorporate the Statement of fact strategy in up to five - member combinations with Redirecting and Statement of fact (\#7 respondent 5, column 1 in Table 3), Statement of fact and Statement of limit (added to enhance the effect of the former - \#7 respondent 40, column 2 in Table 3) or Statement of fact and Willingness (\#7 respondent 39, column 3 in Table 3) being stable constituents of these multiple strategy combinations.

(5) “Съжалявам, но съм натоварен до краен предел и не бих могъл да го направя без това да повлияе отрицателно на качеството на изпълнение на задачите, по които аз работя. Смятам, че ще бъде по-добре ако някой друг ги поеме или ако ги разпределите между повече хора." I am sorry, but I am inundated up to my limit and I would not be able to complete it without this affecting negatively the quality of the tasks which I work on. I deem it better if someone else takes them on or if we split them among more people. (Regret/ Apology + Statement of fact +Voicing Fears + Redirecting)

(40) "Имам твърде много задачи и няма да мога да поема и тези. Не мога да осигуря качество на работата си, ако съм претоварена." - I have too many tasks and cannot take these on. I cannot secure quality of my work if I am overwhelmed with work. (Reason/ Explanation + Negation of proposition+ Statement of fact + Statement of limit)

(39) “С удоволствие, но времето и усилието, което ще прекарам, ще се отрази зле на собствениете ми задачи, а еди кой си мой проект има 
краен срок утре.” - I would love to, but the time and the efforts I will waste will affect negatively my own tasks, besides my project is due tomorrow. (Willingness + Voicing Fears + Statement of fact)

Table 3. Multiple strategy combinations used by BNSs

\begin{tabular}{|r|l|l|}
\hline RA SF- VF - RSE & RSE - CO-SF - SL & Will - Cond \\
\hline PI - RE - RSE - SF - Warn & $\mathrm{RE}-\mathrm{NP}-\mathrm{SF}-\mathrm{SL}$ & $\mathrm{Will}-\mathrm{Q}-\mathrm{SF}$ \\
\hline & $\mathrm{SF}-\mathrm{SL}-\mathrm{Will}-\mathrm{VF}$ & Will $-\mathrm{VF}-\mathrm{SF}$ \\
\hline
\end{tabular}

The current study was designed to complement the existing pragmatics literature on refusals with respect to one little researched linguistic group, namely that of Bulgarian native speakers. A possible explanation for the scarcity of research on the topic of refusals with focus on Slavic languages may be that a pragmatic failure is unlikely to occur in the interaction between the above mentioned cultural groups. This proposition is confirmed by Nixdorf's findings (2002) that there are many similarities in the linguistic resources the three cultural groups she investigated (German, English and Russians) employ. One of the few features in realizing refusals that sets them apart is "the frequent use of the direct "no" in combination with a grateful expression in German (nein, danke) and English (no, thanks), while in Russian the formula most often used is a simple spasibo without any direct "no"' (Nixdorf, 2002, p.124 cited in Siebold \& Busch, 2014). Siebold and Busch (2014), however, assert that even "in apparently similar occidental cultures, like the German and Spanish cultures, there also exist considerable differences between the systems of verbal politeness and communicative styles" (p.66).

\section{Conclusion}

These results show that there is a close similarity in strategy use between English and Bulgarian native speakers at the higher status level. Due to the significant overlap of strategy use a pragmatic failure is unlikely to occur, but if the interlocutors are to engage in more sophisticated communication, attention needs to be paid to the minute peculiarities. These findings are valuable for anyone engaged in teaching TESOL courses, business communication or negotiations as they show the practice of native English speakers and its implications when it comes to realizing the speech act of refusal.

There are a number of limitations that are to be addressed regarding the present research. First and foremost, the data collection tool, namely DCTs confines the samples only to single-turn refusals, which leaves us with a fragmented picture of what the real, spontaneous and interest-driven exchange between interlocutors 
could be. Secondly, the DCTs scenarios although grounded in business settings produce contrived responses and show only probabilistic linguistic behavior. These significant limitations come to show the need for additional research on the topic of refusals in business communication. Our recommendations for subsequent projects focusing on the issue are to aim at collecting naturalistic data. Having mentioned that, we would like to point the challenges that such a project could entail. The very nature of refusals, being a face-threatening speech act, makes the disclosure of information an extremely sensitive subject. This coupled with the secrecy inherent to corporate cultures and prohibition to infringe on corporate secrets and internal rules makes the researcher-outsider into a not very welcome figure.

\section{References:}

Al-Eryani, A. (2008). Refusal strategies by Yemeni EFL learners. Iran. EFL J., 1 (2), 84-104.

Al-Issa, A. (2003). Sociocultural transfer in L2 speech behaviors: Evidence and motivating factors. International Journal of Intercultural Relations, 27, 581601.

Al-Kahtani, S. A. L. (2005) Refusals realizations in three different cultures: A speech act theoretically-based cross cultural-stud. Journal of King Saud University, 18, 35-57.

Al-Shalawi, H. Gh. (1997). Refusal strategies in Saudi and American cultures in Saudi and American cultures. Unpublished Master's Thesis, Michigan State University, Michigan.

Beebe, L., Takahashi, T., \& Uliss-Weltz, R. (1990). Pragmatic transfer in ESL refusals. In R. Scarcella, E. Andersen \& S. D. Krashen (Eds.), On the Development of Communicative Competence in a Second Language (pp. 5573). New York: Newbury House.

Chen, X., Ye, L., \& Zhang, Y. (1995). Refusing in Chinese. In G. Kasper (Ed.), Pragmatics of Chinese as a native and target language (pp. 119-163). Hawaii: University of Hawaii Press.

Cho, Y. (2007). Refusal and Politeness in Directive Action Games. Cultural Differences between Korean and German. In M. Grein \& E. Weigand (Eds.) Dialogue and Culture, (pp. 191-213). Amsterdam: John Benjamins

Honglin, L. (2007). A comparative study of refusal speech acts in Chinese and American English, Canadian Social Science, 3(4), 64-67.

Jiayu, L. (2004). A Contrastive Study of Refusal Strategies between English and Chinese. Thesis presented for The Degree of Master of Arts in the School of Foreign Studies of Anhui University, Anhui University. 
Lauper, J. (1997). Refusal strategies of native Spanish speakers in Spanish and in English and of native English speakers in English. Paper presented at the annual meeting of the teachers English to speakers of other languages. Orlando, FL.

Liao, C., \& Bresnahan, M. (1996). A contrastive pragmatic study on American English and Mandarin refusal strategies. Language Sciences, 18(3), 703-727

Mitkova, P. (2018). Refusal strategies in business communication of native English Speakers. International Journal of Knowledge, 23(5), 1443-1448, Skopje, Macedonia.

Salazar, P., Safont, M., \& Codina, V. (2009). Refusal strategies: A proposal from a Sociopragmatic approach. RAEL: Revista Electronica de Linguistica Aplicada, (8), 139-150.

Scollon, R., \& Scollon, S. (1995). Intercultural communication: A discourse approach. Oxford: Basil Blackwell

Siebold, K., \& Busch, B. (2014). (No) need for clarity - Facework in Spanish and German refusals. Journal of Pragmatics 75, 53-68

Shishavan, H., \& Sharifian, F. (2016). The refusal speech act in a cross-cultural perspective: A study of Iranian English-language learners and AngloAustralian speakers. Language and Communication, 47, 75-88.

The quiz is to be found at: https://docs.google.com/forms/d/1j3D4868dRa261k28z IGJpDdhnpW3cPwECcLKfaay7R0/edit

https://docs.google.com/forms/d/1d79dG9iCf1NeAotQDPdpuVlbMix92DoN1SAS wYRIK30/edit

\section{Appendix A. PSYCHOLINGUISTIC EXPERIMENT - How do you refuse?}

age: gender: nationality: occupation: education:

1. A colleague invites you to her party. $=$

2. Your boss asks you to stay late at work the day before your birthday. $\downarrow$

3. Your colleague asks you to use your laptop. $=$ 
4. The cleaning lady in your office asks you to help her carry a heavy box. $\uparrow$

5. Your boss asks you to give him a lift back home. $\downarrow$

6. A colleague is badly injured and people from work ask you to donate money.

$=$

7. Your boss asks you to take up the tasks of someone who just quit the job. $\downarrow$

8. Your client asks you to clean up the mess she created - spilled coffee on the floor. $\uparrow$

9. A colleague asks to use the printer because he is in a hurry. $=$

10. An employee/student asks you for a day off. $\uparrow$

11. The new colleague asks you to turn down the ringing sound of your cell phone as it is disturbing his work. $\downarrow$

12. Your assistant asks you to call a taxi for her. $\uparrow$ 